\title{
Paideusis
}

\section{From the Editor...}

\section{Sheryle Bergmann Drewe}

Volume 14, Number 2, 2001

URI: https://id.erudit.org/iderudit/1072794ar

DOI: https://doi.org/10.7202/1072794ar

See table of contents

Publisher(s)

Canadian Philosophy of Education Society

ISSN

0838-4517 (print)

1916-0348 (digital)

Explore this journal

Cite this document

Bergmann Drewe, S. (2001). From the Editor... Paideusis, 14(2), 3-4.

https://doi.org/10.7202/1072794ar

This document is protected by copyright law. Use of the services of Erudit (including reproduction) is subject to its terms and conditions, which can be viewed online.

https://apropos.erudit.org/en/users/policy-on-use/
This article is disseminated and preserved by Érudit.

Érudit is a non-profit inter-university consortium of the Université de Montréal, Université Laval, and the Université du Québec à Montréal. Its mission is to promote and disseminate research.

https://www.erudit.org/en/ 


\section{From the Editor}

The issue of standards and assessment is central to current educational reform in North America (and beyond). The theme of evaluation has serendipitously emerged in this issue of Paideusis. We hope you enjoy Barbara Applebaum's "Rigorous Standards, At What Price? Or What Will Our Students Learn When No One is Looking?" and Dennis Cato's "Outside/Inside: CriterionReferenced Assessment and the Behaviourist-Constructivist Dilemma." Although John Halliday's "Post-Modernism and Post-Compulsory Education" does not refer specifically to standards and assessment, the postmodern project questions the whole notion of standards. As always, we welcome your comments in the form of "Reader Responses."

As well as articles and reader responses, Paideusis also publishes book reviews and critical discussion. If you have a book you would like reviewed or if you would like to review a particular book, please contact the Book Review Editor, John Portelli (his address can be found in the "Information for Contributors" on the last page). We hope you enjoy the reviews by Ursula Kelly and Paul O'Leary in this issue.

When considering your summer writing projects (!), we would like to remind you of the special theme of the spring 2002 issue: "How does Philosophy of Education 'Fit' in Today's World?" Papers submitted for this special issue should focus on what philosophy of education has to offer (or is no longer able to offer) today's educational systems. Papers can be critical and/or justificatory in nature and may include contributions from historical as well as contemporary philosophers of education and educational theorists. The deadline for papers to be considered for this special issue will be October 15,2001 . If you have any questions concerning this special issue, please contact myself (my address can be found in the "Information for Contributors" on the last page).

On a sad note, we want to remember Murray Elliott, who passed away this spring. We have included a tribute to Murray in this issue. As difficult as it is to look at the "bright side" in situations like these, we need to remember Murray's passion for philosophy of education. In the words of a long-standing colleague of Murray's: "On Murray's view, practitioners in this field must be not only competent philosophers but also possessed of a broad understanding of educational theory, policy and practice, as well as the issues associated with them." It is this tying together of philosophy and the real world of education which Murray exhibited throughout life and which we are trying to capture in the special issue concerned 
with the question "How does Philosophy of Education 'Fit' in Today's World?".

Sheryle Bergmann Drewe

June 15, 2001 